\title{
A Survey of Discretionary Position in Fiqh and Objective Law
}

\author{
Razieh Najafi $^{1}$ \\ ${ }^{1}$ Department of Law, Sowmesara Branch, Islamic Azad University, Sowmesara, Iran \\ Correspondence: Razieh Najafi, Department of Law, Sowmesara Branch, Islamic Azad University, Sowmesara, \\ Iran. E-mail: Ms.yahyapour@yahoo.com
}

Received: June 6, 2016 Accepted: June 27, 2016 Online Published: June 29, 2016

doi:10.5539/jpl.v9n5p309 URL: http://dx.doi.org/10.5539/jpl.v9n5p309

\begin{abstract}
Discretionary is Chastisement and Punishment that its type and amount has not been determined in the law and Fiqh (Islamic law), and is at the discretion of ruler, or in more correct word, is at the discretion of the judge; Since, according to Article 4 of the Iranian constitution, the laws should be originated from Fiqh, arranged discretionary in Islamic Penal Code and Fiqh is same in many cases. This article tries to investigate discretionary characteristics in the Penal Code and Fiqh; and answer to this problem that, prescribed discretionary in law and Fiqh, to what extent are aligned and have similar dimensions to aforementioned characteristics.
\end{abstract}

Keywords: crime, punishment, discretionary, Fiqh

\section{Introduction}

In the current world, in accordance with scientific and technical developments in social levels, expansion, diversification and emergence of new crimes have been undeniable, and is increasing each day; so that, the world involved in evils, wickedness and different criminality. The overwhelming majority of emerging crimes are discretionary ones. On the other hand, although jurists, from the past to present, have investigated various jurisprudential issues, and explored them through accurate legal reasoning (Ijtihad), unfortunately, there are little researches on discretionary despite its importance. The most obvious reason of this policy is that the realization of the objective discretionary is in the territory of ruler's powers, and practically is depended to the authority of Imam and the formation of political system based on Imamat; and since in the past, cruel and unjust rulers were responsible of the government, the Shiite jurists considered entering the political affairs and having responsibility in judicial acts as helping cruel. Moreover, because the judiciary was attributed to tyrant governments, and they were unqualified, jurists believed that expressing discretionary issues and their details are useless; therefore, just have proposed problems related to discretionary in prescribed Islamic punishments.

Peer reviewing law books reveal that, punishment in Islam is divided into several categories and groups, which are: Islamic punishments, blood money, retaliation, and discretionary; the last one, i.e. discretionary, in different directions has certain divisions; on the one hand, it can be legal discretionary punishments and governmental discretionary punishments. On the other hand, they are discretionary and detaining punishments which were the basis of Islamic Penal Code in 1991, and On the other hand, they are determined and absolute discretionary that are imposed by Islamic Penal Code in 2013, and has also introduced orders to specify the differences between these two discretionary.

\section{Definition of the Concept}

The word of ta'zir, has different meanings that one of them is punishing and beating (Esfahani, Bita: 84), or beating without limit (Ibn Manzoor, $1405 \mathrm{AH}$ : 115); discretionary means punishments that its amount and cause and reason are not specified in detail by Saint Legislator (Mohammadi, 1991: 24), and in contrast, there are three other types of punishments that are Islamic punishments, retaliation, and blood money. In other words, since the punishments have no other type, everything that are not belong to three first three type would be discretionary, and mediocrity is inconceivable (Montazeri, Bita: 113); now discretionary sometimes has specified by Saint Legislator, i.e. Prophet Mohammad (pbuh) and Pure Imams (A), and explanation of their punishment has been determined exactly that this type of discretionary is called determined(Khoee, 1986: 63), and the rest, which are major types, either have been not considered as crime by Saint Legislator and are called governmental discretionary punishment (Mousavi Khomeini, $1404 \mathrm{AH}$ : 57) and has been proposed by Islamic rulers to guarantee implementation of laws their regulations by citizens, or, if they are considered as crime, determining 
their Punishment is responsibility of rulers, and this type of discretionary, which is called بما يراه الحاكم are absolute that a major part of discretionary are from this type. In addition, some Islamic Scholars and Jurisprudents, if determined a punishment for a crime, as minimum and maximum, has considered it as determined discretionary, and ruler cannot assign and determine another higher or lower punishment (Makarem Shirazi, Bita: 25).

\section{Characteristics of Discretionary Punishment in Fiqh and Law}

In Fiqh and law, some characteristics are considered to discretionary which are as follows.

\subsection{Indetermination of Amount and Type}

The first point is indetermination of amount and type of discretionary punishment in Islamic law, and devolving to ruler. This point has been appreciated by "Mark Ancel", the founder of modern social defense school (Mohseni, 2013: 162), because, the judge can assign and determine appropriate punishment to offender and committed act, considering their characteristics, which result in correction.

But this point is not compatible with of legality of punishment principle? At first glance, it seems that devolving the amount and the type of discretionary punishment to ruler is in contrast with legality of punishment principle, whereby, the law should determine the amount of punishment before committing a criminal act. But it should be noted that contradiction is in this assumption that the purpose of the ruler is judge, not the plenipotentiary and in other word government. The explanation is that the term of ruler has two meanings: the first one is court judge and others are plenipotentiary and the head of government. Since in the Islamic system, there is no necessity to separate the legislature from judiciary, the ruler has the position of legislation and judiciary. However, if the meaning of "ruler" in the Islamic penal code is a leader of a government, the mentioned meaning is that unlike Islamic punishments, its amount and type of punishment are not specified in the Islamic law, and the ISLAMIC law has devolved its responsibility to the ruler and government, and it is government that in every time, and according to the best interest determine its amount. Then, the points of this definition will be clear by comparing discretionary and preventive punishments.

In other words, the Islamic Penal Code expresses Indetermination of amount of punishment in the Islamic law, but does not encourage it. The law does not say that the court judge is responsible of determining the amount of discretionary. Therefore, we see that in the Act of discretionary in 1983, in the Islamic penal code, as well as in other laws, it is legislator who determine the amount of discretionary punishment, and specify minimum and maximum to it, so that, it does not contradict with legality of punishment.

\subsection{Chastisment and Punishment}

The question is that are there differences between "chastisement" and "punishment" and or these two terms imply the same concept? Basically, always the words, especially the words related to the law should be considered as established ones. The main point is that every word has a different meaning from the applied other word. The law is not place of emphasizing and additional description. The principle in development of law is that every word has a special meaning. According to this principle, it is assumed that, there are differences between "chastisement" and "punishment". What are the differences between these two words?

It is possible that differences between chastisement and punishment been in a person who will be punished. This means that punishment is a discretionary that will be done to responsible person; but, chastisement is a discretionary punishment on irresponsible persons such as insane and child.

Some evidence can be found in the Islamic penal code about this issue. For example, in the case of child it has been said: "if chastisement is effective to offender, he/she will be chastised according to the court". The following actions are not considered as crime: 1. the acts of parents, legal guardians, legal guardian of the minors, and incapacitated persons, which will be done in order to their chastisement or protection". "Jurists also sometimes have used the word of chastisement to punish irresponsible persons. For example, Shahid Awwal has written: “(Makki, p. 258).

But, it seems better that the differences between punishment and chastisement does not refer to a person who will be punished, but it refers to the type of discretionary punishment. If discretionary punishment include lashing and imprisonment, etc., i.e. Hard and harsh punishments, it is "punishment", and if it includes advising, reprimand, threat, and recording in disciplinary case, and in other word, the acts that their hardship and violence is not so much, the discretionary punishment is called "chastisement".

Some evidence of the Islamic Penal Code 1991 and 2013, confirms this point: "... In this case, the compulsion to punish offender, according to his conditions and facilities, and frequency of committing crime and levels of 
chastisement, will be sentenced to advise, reprimand and threat and different degree of discretionary punishment.

Article 43 also says: "The following persons are considering accessory and will be punished on the basis of their conditions and facilities, and frequency of committing crime and levels of chastisement, by advise, reprimand and threat and different degree of discretionary punishment".

In these two articles, "advise, reprimand and threat" are explanation to levels of chastisement.

The idea can be seen as complementary to previous view. In other words, assuming that the legislator has called the punishment of the responsible persons, discretionary punishment, and the punishment of irresponsible persons, chastisement, this act will be performed not because of perpetrator of criminal act, but because of punishment and sanctions. Since the sanctions of acts performed by insane and minor and persons without criminal liability, as a rule differ from sanction of responsible people in terms of intensity, hardship and gentleness, so their discretionary punishment is called chastisement.

\subsection{Being Allegorical}

The cases that has been stated by Islamic penal code to discretionary punishment (imprisonment, money judgment, and lash) are allegorical not limitative; because it states "such as". Consequently, the legislator can use other punishments to discretionary, as it has done.

\subsection{Less Than Islamic Punishment}

If lashing is used to discretionary punishment, its amount should less than Islamic punishment. This point is the result of the rule of "التعزير دون الحدّ", which is dominant on discretionary. Of course, this rule is not only performing on lashing, but also on the other punishments; therefore, life imprisonment and execution cannot be used in discretionary.

The question that arises is that, what is the meaning of Islamic punishment, in which the amount of lashing should be less than it? Is it Islamic punishment of adultery which is 100 lashes or 75 lashes of panderism? Or etc. There is controversy on this issue; some scholars have narrated from eleven jurists (Montazeri, vol. 3, pp. 539-537). Since the expression of all of them is outside the scope of this paper, only two important one will be mentioned.

First opinion: Islamic punishment means the least Islamic punishment, which is the same as Panderism (75 beats). As a result, the amount of discretionary punishment should not exceed 74 lashes.

Second opinion: Islamic punishment means a punishment which is proportional to target discretionary crime. If someone is committed a discretionary crime in relation to adultery, such as kissing and copulation, his/her punishment will be less than adultery (one hundred times). Whenever a person commit any offense that is proportional to false accusation of adultery, its punishment is less than false accusation of adultery, but, if a person commit any crime that is not proportional to any kind of discretionary crime, such as fraud, bribery, and usury, his/her punishment is less than the least Islamic punishment, i.e. Islamic punishment of panderism (Ameli, vol. 9, p. 193).

Let us now consider that the legislator has followed which one of the two mentioned views in the Islamic penal code. By studying the Islamic penal code, we find that the amount of discretionary lashing is one of the following items:
A) To 74 lashes
B) To 99 lashes
C) To 60 lashes

According to these, we can say:

Firstly, the legislator did not act according to the first approach, because discretionary punishment less and more than 74 lashes are not anticipated.

Secondly, the second approach also has not been applied. Because, although the articles 123, 134 and 637 in the Islamic penal code, which are on kissing and copulation are suitable to crimes such as sodomy and lesbianism, therefore, their punishment are up to 99 lashes, but violations of this methods in this law are a lot:

A) Article 124, which is about kissing two men or two women, has been anticipated one to sixty lashes; which is unprecedented even in the law of Islamic punishment and retaliation approved in 1982. It is clear that if the legislator has followed the first opinion, should anticipated punishment up to 74 lashes, and if act as second 
approach 99 lashes should be followed. There are no criteria to punishment of sixty lashes.

Since kissing men and women has been anticipated in article 637 of the Islamic penal code, article 124 of this law is not about kissing these two, and certainly includes kissing two men. But, how about kissing two women? It may be said that since this article has been discussed about sodomy, does not include kissing of two women, and it may be argued that it is due to absoluteness of this article, and because the legislator has used the word of "person" and "other" instead of "man"; the article include kissing of two women. Under Islamic punishment and retaliation law, in 1982, not only 60 lashes, but also 99 lashes was not anticipated in Articles, and just the phrase of discretionary has been mentioned.

B) Since the discretionary crimes of shopping, transporting and constructing Alcoholic liquor are proportional to the offense of drinking Alcoholic beverages, should be determined to 79 lashes, because the punishment of drinking intoxicants is 80 lashes. However the legislator has anticipated the punishable up to 74 lashes in Articles 175, 702, 703 and 704 of this Act.

C) If attributing adultery or sodomy was not explicitly, which leads to Islamic punishment of false accusation of adultery, or attributing a prohibited act except adultery or sodomy been as lesbianism, its punishment should be up to 79 lashes (Islamic punishment of false accusation of adultery is 80 lashes).

Whereas in different Articles to false accusation of adultery and discretionary, the punishment of 74 lashes has been anticipated.

It is observed that legislator has followed first opinion more than second one; because punishment more than 74 lashes, and up to 99 lashes in Articles123, 134 and 637 of the Islamic penal code, is because of legislator's willingness to follow Islamic law in discretionary that their amount has been determined in Islamic law, and discretionary punishment to the case of these three Articles, which is kissing and copulation has been determined in Islamic law.

Of course, in the case of kissing and copulation, there are different traditions and narratives that can be classified in four groups (Montazeri, Bita., pp. 39-34)

1) Traditions that implies 100 lashes as a punishment;

2) Narratives that has anticipated 99 lashes;

3) Narrative that has determined 30 lashes;

4) Traditions that have not considered it as Islamic law, and believe in discretionary punishment, but its amount have not been determined. Traditions do not mentioned up to 99 lashes, but they anticipated 99 lashes, however, jurists have used it, which can be up to 99 lashes.

\section{Conclusion}

Discretionary is Chastisement and Punishment that its type and amount has not been determined clearly in the Islamic law, and is determined based on the discretion of Islamic ruler, but some of these discretionary have been determined exactly by Prophet Mohammad (pbuh) and Pure Imams (A), that this latter one, is called determined discretionary; Islamic legislator, in 2013, has developed rules to this type of discretionary, without mentioning and counting determined discretionary, so that these discretionary do not involved in passing time, suspension and postponement etc.; in short, the legislator due to his rigidity and prejudice toward the word of imams(a) and jurists, has emphasized the same order that are in narrations and traditions, and believe its transforming by legal institutions and even at the discretion of the judge and Islamic is not allowable.

Before the Islamic revolution of Iran, punishments mainly were divided to three types of crimes, misdemeanors and malefaction, and after the revolution it has been classified to the Islamic punishment, retaliation, blood money, and discretionary. However, it should be acknowledged that the Islamic penal code, somehow, is a combination of regulations before and after the Islamic revolution.

Although it might be argued that, since quintuple classification of punishments in the Islamic penal code have no practical benefits, similar effects can be considered to discretionary, but in fact it is not true; because, discretionary and deterrent punishments have important differences, which can be the origin of various effects. Of course, it should be acknowledged that the current situation the Islamic penal code is such that as if these two punishments have the same effects and rules and just have credit difference.

\section{References}

Esfahani, Ragheb; mojam, Beirut, Beta1423.

Ibn Manzoor, Muhammad, Qom, Adab Hoze publishing, in 1405 AH. 
Khoee, A. (1986). mabani takmalah almenhaj khoee. Qom, Rehabilitation Institute of Imam Khoee's works.

Makarem Shirazi, N. (n.d.). analysis of discretionary in Islam. Tehran, Noore Elm, Bita1404.

Mohammadi, A. (1995). criminal law of Islam. Tehran, Nobahar Publishing.

Mohseni, M. (2013). a review of general criminal law (Vol, I). The National University of Iran.

Montazeri, H. A. (n.d.). jurisprudential basics of Islamic government (Vol. 3) translated by Abolfazl Shakoori. Keihan Publications.

Montazeri, Hossein Ali; Bita, Qom, Bina 1409.

Mousavi Khomeini, Ruhollah; Tahrir ol Vasile, Qom, Islamic Publications, 1404 AH.

\section{Copyrights}

Copyright for this article is retained by the author(s), with first publication rights granted to the journal.

This is an open-access article distributed under the terms and conditions of the Creative Commons Attribution license (http://creativecommons.org/licenses/by/3.0/). 